\title{
What Is Marine Biodiversity? Towards Common Concepts and Their Implications for Assessing Biodiversity Status
}

\begin{abstract}
Sabine K. J. Cochrane ${ }^{1,2 *}$, Jesper H. Andersen ${ }^{3}$, Torsten Berg ${ }^{4}$, Hugues Blanchet ${ }^{1,5}$, Angel Borja ${ }^{6}$, Jacob Carstensen ${ }^{7}$, Michael Elliott ${ }^{8}$, Herman Hummel ${ }^{9}$, Nathalie Niquil ${ }^{10}$ and Paul E. Renaud ${ }^{2}$

${ }^{1}$ SALT Lofoten AS, Svolvær, Norway, ${ }^{2}$ Arctic R\&D Department, Akvaplan-niva, Troms $\varnothing$, Norway, ${ }^{3}$ NIVA Denmark Water Research, Copenhagen, Denmark, ${ }^{4}$ MariLim Aquatic Research GmbH, Schönkirchen, Germany, ${ }^{5}$ University of Bordeaux, UMR EPOC, Pessac, France, ${ }^{6}$ Marine Research Division, AZTI Tecnalia, Pasaia, Spain, ${ }^{7}$ Department of Bioscience, Aarhus University, Roskilde, Denmark, ${ }^{8}$ Institute of Estuarine and Coastal Studies, University of Hull, Hull, UK, ${ }^{9} \mathrm{NIOZ}$ Royal Netherlands Institute for Sea Research, Yerseke, Netherlands, ${ }^{10}$ Centre National de la Recherche Scientifique/Université Caen Normandie, BOREA, Caen, France
\end{abstract}

OPEN ACCESS

Edited by:

Marianna Mea

Ecoreach srl, Italy; Jacobs University

of Bremen, Germany

Reviewed by:

Ricardo Serrão Santos,

University of the Azores, Portugal

Christos Dimitrios Arvanitidis,

Hellenic Centre for Marine Research,

Greece

${ }^{*}$ Correspondence: Sabine K. J. Cochrane sabine@salt.nu:

sc@akvaplan.niva.no

Specialty section

This article was submitted to Marine Ecosystem Ecology, a section of the journal Frontiers in Marine Science

Received: 15 July 2016 Accepted: 14 November 2016 Published: 15 December 2016

Citation:

Cochrane SKJ, Andersen JH, Berg T, Blanchet H, Borja A, Carstensen J, Elliott $M$, Hummel $H$, Niquil $N$ and Renaud PE (2016) What Is Marine Biodiversity? Towards Common Concepts and Their Implications for

Assessing Biodiversity Status.

Front. Mar. Sci. 3:248

doi: 10.3389/fmars.2016.00248
Biodiversity' is one of the most common keywords used in environmental sciences, spanning from research to management, nature conservation, and consultancy. Despite this, our understanding of the underlying concepts varies greatly, between and within disciplines as well as among the scientists themselves. Biodiversity can refer to descriptions or assessments of the status and condition of all or selected groups of organisms, from the genetic variability, to the species, populations, communities, and ecosystems. However, a concept of biodiversity also must encompass understanding the interactions and functions on all levels from individuals up to the whole ecosystem, including changes related to natural and anthropogenic environmental pressures. While biodiversity as such is an abstract and relative concept rooted in the spatial domain, it is central to most international, European, and national governance initiatives aimed at protecting the marine environment. These rely on status assessments of biodiversity which typically require numerical targets and specific reference values, to allow comparison in space and/or time, often in association with some external structuring factors such as physical and biogeochemical conditions. Given that our ability to apply and interpret such assessments requires a solid conceptual understanding of marine biodiversity, here we define this and show how the abstract concept can and needs to be interpreted and subsequently applied in biodiversity assessments.

Keywords: conceptual models, marine biodiversity, ecosystems, food-webs, components, assessment

\section{INTRODUCTION}

The term "biodiversity", first used almost three decades ago as a derivative of "biological diversity" (Wilson, 1985, 1988) today is one of the most often cited terms in both ecological research and environmental management and conservation (i.e., 141,214 papers in ISI Web of Science, as consulted on 27th April 2016). However, its precise definition and our understanding of the concept varies widely both between and within disciplines. Biodiversity is recognized to encompass "... the 
variability among living organisms from all sources including, inter alia, terrestrial, marine, and other aquatic ecosystems and the ecological complexes of which they are part; this includes diversity within species, between species and of ecosystems." (CBD, 1992). The elements of biodiversity are fundamental properties of an ecosystem, and, in the marine realm, these encompass all life forms, including the environments they inhabit, and at scales from genes and species to ecosystems (see Wilson, 1988; Boero, 2010). Biodiversity can be described as an abstract aggregated property of those ecosystem components (Bengtsson, 1998) and can relate to the structure or function of the community where structure relates to the system at one time whereas functioning relates to rate processes (Gray and Elliott, 2009). The structural aspect is represented by the various marine life-forms, ranging from the smallest prokaryote to the largest mammal, and inhabiting some of the most extreme environments. These species exhibit a diversity that probably exceeds that found in terrestrial environments (Heip, 1998, 2003). The functional aspect is represented by the relationships among and between these marine organisms and the environments they inhabit, and is defined in terms of rates of ecological processes (Strong et al., 2015); most notably they include physiological processes, predator-prey relationships, trophic webs, competition, and resource partitioning. These functions vary on both temporal and spatial scales (Solan et al., 2006), and include some of the most important ecosystem services, including oxygen provisioning, $\mathrm{CO}_{2}$ sequestration, and re-mineralization of nutrients (Duarte and Cebrian, 1996; Costanza et al., 1997; van den Belt and Costanza, 2012). Both structural and functional elements contributing to biodiversity play a fundamental role in maintaining and defining healthy marine systems (Selig et al., 2013).

In essence, the marine ecosystem is comprised of three interlinked processes (Gray and Elliott, 2009). Firstly, the physico-chemical system creates a set of fundamental niches (most often the water column and substratum) which then are colonized by organisms according to their environmental tolerances-these may be termed environment-biology relationships. Secondly, the organisms interact with each other in, for example, predator-prey interactions, competition, recruitment, feeding, and mutualism-these are biologybiology relationships. Thirdly, the resulting ecology has the ability to complete the cycle with feedback loops and modify the physico-chemical system through bioturbation, space or material removal or change, bio-engineering, for example; these may be termed biology-environment relationships. Superimposed on these three systems are anthropogenic influences which then perturb the systems.

Human activities produce a range of pressures on marine systems, some of which may lead to irreversible changes (e.g., deyoung et al., 2008; Elliott et al., 2015). This may have immediate consequences for patterns of biodiversity and consequently for the critical ecosystem services they provide (Costanza et al., 1997, 2014; De Groot et al., 2002, 2010). Those ecosystem services can be grouped into provisioning, regulating, supporting and cultural ones which, after adding human complementary assets, in turn lead to societal benefits (Turner and Schaafsma, 2015).

In this context, the European Marine Strategy Framework Directive (MSFD) requires Member States to achieve Good Environmental Status (GES) (European Commission, 2008). The directive comprises 11 qualitative descriptors of GES, of which biological diversity is the first, but most if not all of the others can be considered to refer to some part of biodiversity in its broad sense, assuming we also consider habitats and their condition as being within the term; indeed it can be assumed that if the biodiversity descriptor has been satisfied then by definition all others are satisfactory and vice versa (Borja et al., 2013). In order to know whether the goal of GES has been achieved, an assessment needs to be performed that measures the current environmental status, hence this involves quantifying the abstract ecosystem feature biodiversity. For this, the European Commission has defined a number of GES criteria and indicators that represent and quantify various aspects of environmental status and biodiversity (European Commission, 2010). The available indicators in Europe, for the MSFD implementation, have been recently collated (Teixeira et al., 2016), and a method to select the most adequate has been proposed (Queiros et al., 2016). Then, some of them have been used in assessing the environmental status across regional seas (Uusitalo et al., 2016).

It is axiomatic that one cannot manage a system unless it can be measured and those measures require to be SMART (Specific, Measurable, Achievable, Realistic, and Time-bounded) otherwise it is not possible to determine whether management has achieved the desired result (Elliott, 2011). Hence the importance of quantitative indicators but these must be comparatively simple if they are to be operational (Rombouts et al., 2013; Borja et al., 2016), although many of these overlap, and such redundancies can compromise the efficiency and accuracy of assessments (Berg et al., 2015). The recent trend toward using long lists of indicators for an integrative assessment increases the risk of such overlaps (Teixeira et al., 2016). There are many potential combinations of study approaches and thus, before compiling the indicators, any large-scale or comparative assessment of biodiversity first requires a unified approach and a workable conceptual understanding of biodiversity.

Given the inherent complexity of biodiversity and the services which the ecosystems provide as a consequence of their biodiversity (see, for example, Heip, 2003; Bartkowski et al., 2015; Farnsworth et al., 2015), it is imperative to depict these into one or more simple conceptual models. There are many ways to view marine systems, depending on the questions asked, the management goals set and typically, as with any complex system, disaggregating the various levels of complexity allows us to better understand each of the components and their major interactions (Brooks et al., 2016). Consequently, an assessment of biodiversity used to answer a specific question will benefit from a set of conceptual models which together represent the various aspects of biodiversity. Together, these models provide a multi-faceted view of biodiversity and help users to identify the necessary elements to include in an environmental assessment by focusing on the aspects of biodiversity most relevant to the specific question and goal. 
A common conceptual framework on marine biodiversity is presented here to facilitate integrative assessment of environmental status and implementation of the relevant legislation. We present a context-driven, multi-faceted view on biodiversity that will enable selection of the appropriate assessment elements and indicators. The framework is required to implement and further develop policies and practice to maintain biodiversity in the context of the sustainable management of human activities.

\section{CONCEPTUAL VIEWS OF BIODIVERSITY}

Marine biodiversity is an aggregation of highly inter-connected ecosystem components or features, encompassing all levels of biological organization from genes, species, populations to ecosystems, with the diversity of each level having structural and functional attributes (Table 1). Further, marine biodiversity, or any of its components, can be assessed at various temporal or spatial scales. A conceptual model of marine biodiversity and its interpretation therefore depends on the questions being asked, which of the different components are emphasized, and the information and understanding available, especially of the connectivity and feedbacks in the system. By definition, this involves the implicit understanding that the components are all part of a larger and inter-linked system, where changes in one element inevitably will produce knock-on effects elsewhere (Gamfeldt et al., 2015). These may be regarded as bottom-up processes, causing change from the cell to the ecosystem and from the physicochemical system to the landscape ("seascape") system. Similarly, they can be regarded as the responses in a top-down system focusing on the upper level (seascape and ecosystem) which is often the end-point of marine management and the focus of the current review. Accordingly, this review does not specifically address genetic, molecular, physiological, biochemical, population, and size-biomass-spectrum aspects of biodiversity (Zacharius and Roff, 2000; Kenchington, 2003; Palumbi, 2003; Gray and Elliott, 2009), as these are both intrinsic and implicit aspects within the concept of biodiversity, whichever viewpoint is emphasized. We thus specifically cover only the upper levels (Table 1, bold entries), but retain the understanding of the multi-level complexity within these.

Hence modeling such a complex system with a view to marine management requires (i) pragmatic simplifications through disaggregation of the elements into various conceptual viewpoints, followed by (ii) a context-driven re-aggregation of the necessary components. We here provide three illustrative examples of such conceptual upper-level views on marine biodiversity, where the information retrieved is restricted to that relevant to the main focus, or viewpoint (Figure 1). The first focuses on structural aspects using a classical taxonomic approach to biodiversity (structural taxonomic biodiversity). The second focuses on the functional aspects of biodiversity (functional ecosystem biodiversity), and the third illustrates food-webs as one of the most used types of a combined view on both structural and functional aspects of biodiversity (foodweb biodiversity). These examples only capture parts of the full complexity of biodiversity (Table 1) but are the most commonly found in specific user-driven contexts.

\section{Structural Taxonomic Biodiversity}

Since the establishment of the hierarchical system of binomial nomenclature (Linné, 1735), a major focus of biological studies has been to categorize observed organisms into taxonomic units, and to describe new species as they are discovered. Quantitative taxonomic data sets are a useful tool in environmental assessments, with typical indicators being species (taxon) richness, and population abundance and biomass within a place, between areas or over time. This is especially important in nature conservation planning (Sarkar and Margules, 2002), notably because habitat destruction is a major driver of species extinctions, particularly those with narrow distribution ranges (Pimm et al., 2014), such that adequate knowledge of the structural taxonomic biodiversity of a particular area will help to preserve its endemic species. A taxonomic inventory and the associated habitats and their changes in space and time then becomes central to environmental impact assessments (Pearson and Rosenberg, 1978; Olsgard and Gray, 1995; Rosenberg et al., 2001; Borja et al., 2003), studies of marine protected areas (Klein et al., 2015) and the compliance with marine diversity and ecosystem health governance instruments such as the EC Habitats Directive (e.g., Boyes and Elliott, 2014).

The EU MSFD addresses biodiversity components within two main categories: (i) main species groups, and (ii) habitats and their associated communities (habitat diversity and mosaics) (see Cochrane et al., 2010; Hummel et al., 2015). The main species-level groups include mammals, birds, fish, cephalopods, and reptiles. Within the marine habitats, watercolumn communities comprise pelagic microbes, phyto- and zooplankton, whereas seafloor communities encompass benthic micro, macro- and mega- fauna as well as primary producers such as seagrasses and macroalgae. In addition, other species such as those included under the European Union legislation or international conventions, charismatic or non-indigenous species and genetically distinct forms (varieties or subspecies) of native species may be included, depending on the particular assessment area and questions being addresses. In the MSFD, the categories for birds, fish, and mammals are further sub-divided into main functional categories, mostly based on their feeding and/or depth preferences (Table 2). This, however, introduces a functional division into the otherwise purely structural view.

The predominant seabed and water column habitat types can effectively be characterized in terms of a pragmatic selection of the major categories under the European Nature Information System (EUNIS) scheme (Cochrane et al., 2010; Galparsoro et al., 2012, 2015) (Table 3). The biological communities associated with those habitats can then be addressed; thus extending the conceptual view from purely taxonomic entities to higher-level structural aggregations of taxa as part of their biotope (Olenin and Ducrotoy, 2006) (Figure 2). This structural view potentially omits the functional attributes or traits of the populations and communities associated with habitats although some of the structural attributes may be regarded as surrogates (proxies) for functional ones (Gray and Elliott, 2009). For example, 
TABLE 1 | Structural and functional biodiversity examples across levels of biological organization (topics focused on in the current paper in bold) (extensively modified from Zacharius and Roff, 2000).

\begin{tabular}{|c|c|c|}
\hline $\begin{array}{l}\text { Level of biological } \\
\text { organization/compositional level }\end{array}$ & Structural diversity & Functional diversity \\
\hline Genes-molecular & $\begin{array}{l}\text { Genetic structure, gene pool; molecular and } \\
\text { biochemical structure }\end{array}$ & $\begin{array}{l}\text { Genetic variability over time, gene pool modification; biochemical } \\
\text { changes in space and time }\end{array}$ \\
\hline Species-individual & Morphological variability, size-biomass spectra & $\begin{array}{l}\text { Physiological variability; environmental tolerance change; growth } \\
\text { variability }\end{array}$ \\
\hline Species-population & $\begin{array}{l}\text { Population structure, recruitment size, biomass } \\
\text { variability }\end{array}$ & $\begin{array}{l}\text { Population dynamics, production and productivity change; } \\
\text { intra-specific relationship changes }\end{array}$ \\
\hline Community & Community composition & $\begin{array}{l}\text { Inter-specific relationship changes; organism-habitat } \\
\text { variability; intra-habitat competition; food-web interactions }\end{array}$ \\
\hline Ecosystem & Ecosystem structure & $\begin{array}{l}\text { Ecosystem processes, predator-prey relationship changes, } \\
\text { inter-habitat competition }\end{array}$ \\
\hline Landscape type & Habitat structure; seascape mosaic & $\begin{array}{l}\text { Physical-biota interaction variability in space and time; } \\
\text { changes to seascape mosaic in space and time }\end{array}$ \\
\hline
\end{tabular}

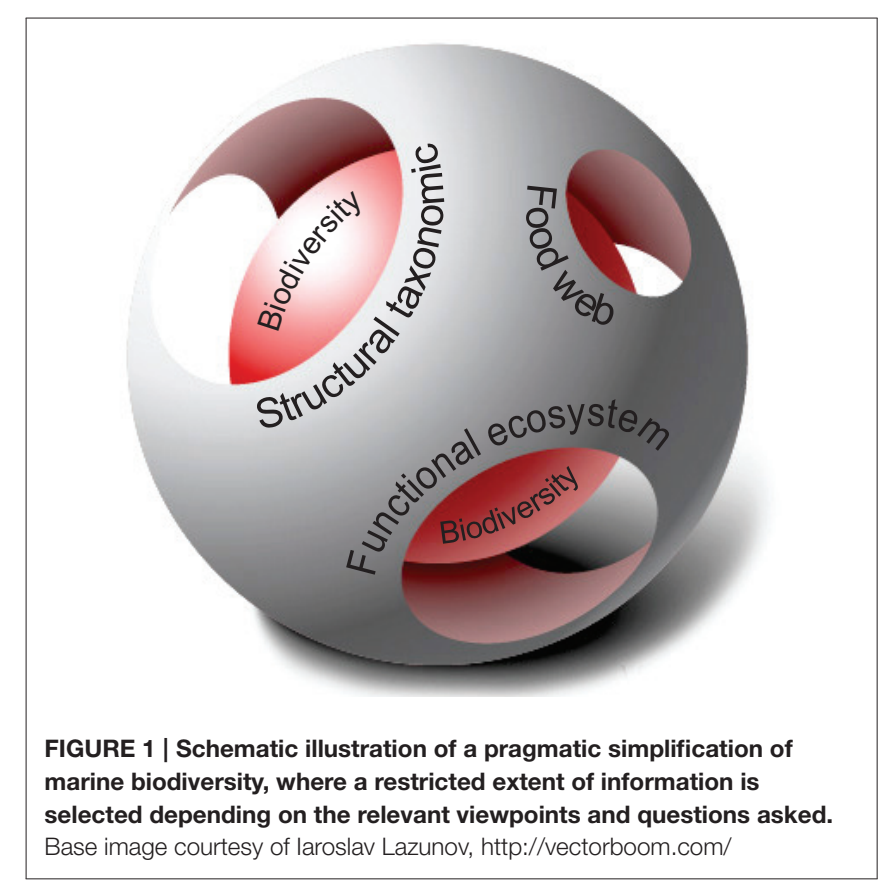

the benthic communities can be characterized in terms of proportional representations of different traits, feeding guilds, motility, burrowing activities etc. (Bremner et al., 2006a,b; Cochrane et al., 2012) but these have not previously been the main focus of structural biodiversity; most methods have centered on the plethora of quantitative means of defining benthic community structure (Gray and Elliott, 2009). However, recognizing and measuring functional diversity within the benthos also has become of increasing importance from a management perspective (Reiss et al., 2015).

A high biodiversity, including species richness, may enhance ecosystem processes and promote long-term stability by buffering, or insuring, against environmental fluctuations (Yachi and Loreau, 1999; Loreau, 2000). Conversely, a loss of biodiversity may impair ecosystem functioning, and thus also
TABLE 2 | Predominant functional and/or feeding groups within the main biodiversity components for application in assessment of motile biodiversity components.

\begin{tabular}{|c|c|}
\hline Biodiversity component & Ecotype \\
\hline Birds* & $\begin{array}{l}\text { Offshore surface-feeding birds } \\
\text { Offshore pelagic-feeding birds } \\
\text { Inshore surface-feeding } \\
\text { Inshore pelagic-feeding birds } \\
\text { Intertidal benthic-feeding birds } \\
\text { Subtidal benthic-feeding birds } \\
\text { Ice-associated birds }\end{array}$ \\
\hline Reptiles & Turtles \\
\hline Mammals & $\begin{array}{l}\text { Toothed whales } \\
\text { Baleen whales } \\
\text { Seals } \\
\text { Ice-associated mammals }{ }^{\star \star}\end{array}$ \\
\hline Fish & $\begin{array}{l}\text { Pelagic fish } \\
\text { Demersal fish } \\
\text { Elasmobranchs } \\
\text { Deep sea fish } \\
\text { Coastal/anadromous fish } \\
\text { Ice-associated fish }{ }^{\star \star}\end{array}$ \\
\hline Cephalopods & $\begin{array}{l}\text { Coastal/shelf pelagic cephalopods } \\
\text { Deep-sea pelagic cephalopods }\end{array}$ \\
\hline
\end{tabular}

"Annex III of the MSFD refers to "seabirds"; this term is commonly used to distinguish certain types of marine birds (petrels, gannets, cormorants, skuas, gulls, terns, and auks) from water birds (waders, herons, egrets, ducks, geese, swans, divers, and grebes). To avoid possible confusion with this narrower use, the term "birds" is used here. The ecotypes for seabirds (offshore and inshore) are as used by the ICES Working Group on Seabird Ecology for assessment of trends in seabird populations (ICES, 2009). **Species which depend upon ice and ice-driven biological processes for habitat, shelter, reproduction or feeding for at least some parts of the year, or for parts of their life-cycle.

the services provided (Loreau and Hector, 2001). At least in the marine realm, habitat structure obviously influences the number of niches available for colonization and thus can indicate the number of types (species, traits, etc.) which can be supported 
TABLE 3 | Predominant habitat types for application in assessment of Descriptor 1.

\begin{tabular}{|c|c|c|}
\hline Realm & Predominant habitat type & Relationship to EUNIS ${ }^{1}$ habitat classes \\
\hline \multirow[t]{9}{*}{ Seabed habitats } & Littoral rock and biogenic reef & $\mathrm{A} 1+\mathrm{A} 2.7$ \\
\hline & Littoral sediment & A2 (except A2.7) \\
\hline & Shallow sublittoral rock and biogenic reef & A3 + circalittoral habitats in A4, infralittoral \& circalittoral biogenic reefs in A5.7 \\
\hline & Shallow sublittoral sediment & Habitats in A5 (except A5.6) above wavebase (from $0 \mathrm{~m}$ down to about 50-70 m depth in Atlantic) \\
\hline & Shelf sublittoral rock and biogenic reef & Deep circalittoral habitats in A4 \& A5.7 \\
\hline & Bathyal rock and biogenic reef & A6.1 + A6.6 (bathyal zone- $200-1800 \mathrm{~m}$ in Atlantic) \\
\hline & Bathyal sediment & A6.2 + A6.3 + A6.4 + A6.6 (bathyal zone- $200-1800 \mathrm{~m}$ in Atlantic) \\
\hline & Abyssal rock and biogenic reef & A6.1 + A6.7 (abyssal zone $-\sim>1800 \mathrm{~m}$ in Atlantic) \\
\hline & Abyssal sediment & A6.2 + A6.3 + A6.4 + A6.6 (abyssal zone- > 1800 m in Atlantic) \\
\hline
\end{tabular}

Pelagic habitats Low salinity water (Baltic Sea)

EUNIS pelagic classification not structured in suitable way for purpose here

Reduced salinity water (Black Sea)

Estuarine water

Coastal water

Shelf water

Oceanic water

Ice habitats

Ice-associated habitats

A8

${ }^{1}$ EUNIS 200611 version used.

Outline depth ranges are given for Atlantic waters for the shallow, shelf, bathyal, and abyssal zones. The precise depth ranges vary between subregions and also in the Baltic, Mediterranean and Black Sea Regions.

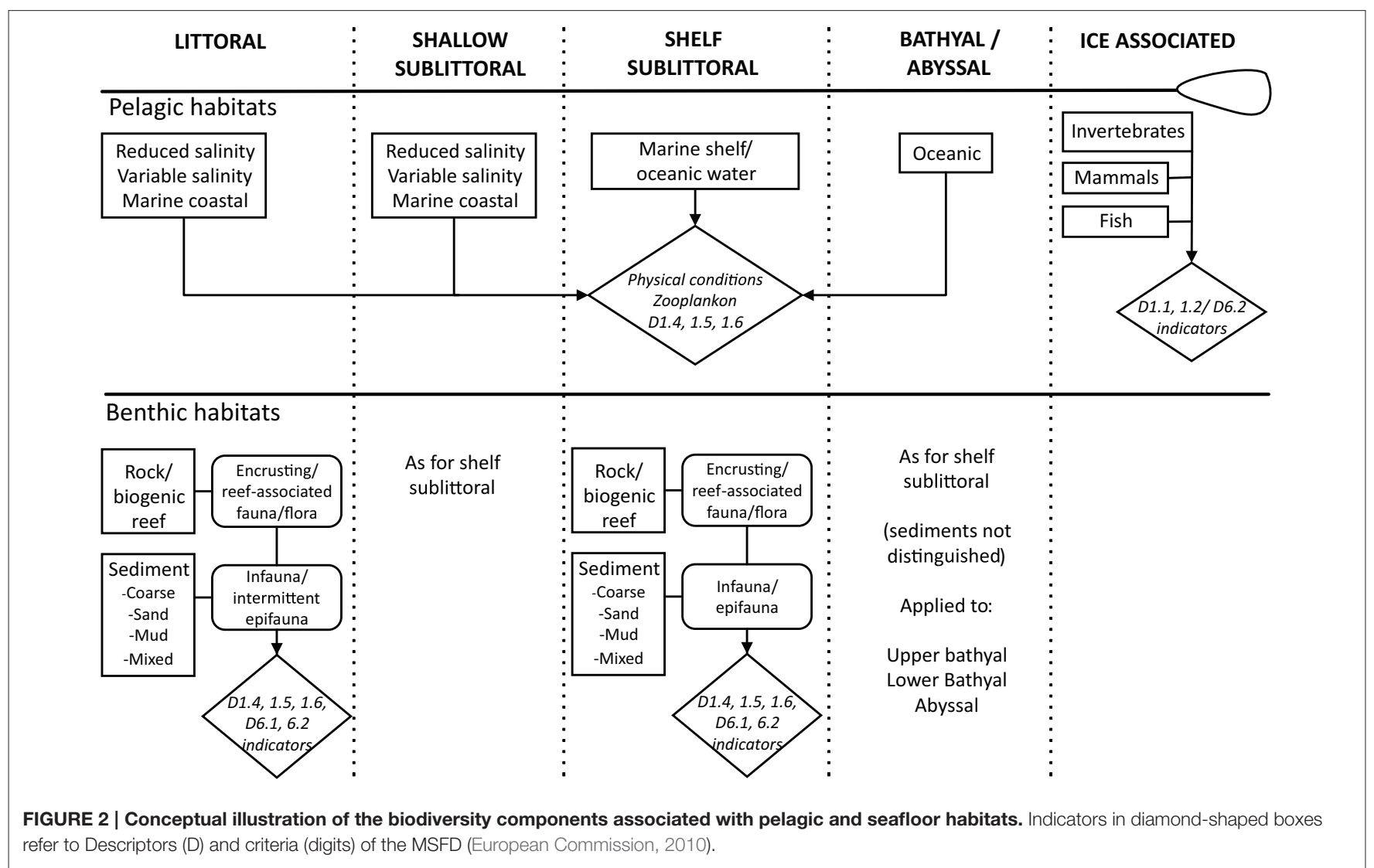


within that habitat. Other community properties such as biomass and abundance are more dependent on ecological interactions such as predator-prey links and recruitment (Gray and Elliott, 2009). This biodiversity-stability relation is complex as it firstly requires a clear definition of what is meant by ecosystem temporal (dynamic) stability and/or the ability to withstand change through resistance and resilience (see McCann, 2000; Tett et al., 2013). Secondly, it requires understanding how biological diversity will enhance ecosystem stability (McCann, 2000; Hooper et al., 2005; Strong et al., 2015). There is a wealth of theoretical and empirical data to support the contention that biodiversity (numbers of distinct species, but also functional diversity) enhances both ecosystem productivity and its resistance to perturbation (e.g., Isbell et al., 2015a,b; Wang and Loreau, 2016). Habitats and species diversity are intrinsically intertwined, and baseline diversity is highly variable. For example, species diversity in seagrass meadows is greater than in adjacent non-vegetated areas (Hemminga and Duarte, 2000), but the lack of seagrass diversity makes these habitats more vulnerable to specific perturbations such as the Wasting disease and storms (Orth et al., 2006). However, this is not always the case as some lower diversity ecosystems, such as estuaries, have a high resilience conferred by the high tolerances and adaptability of the component species, a feature termed environmental homeostasis (Elliott and Quintino, 2007).

While structural taxonomic biodiversity may enhance ecosystem stability, it is not the structural biodiversity as such that causes stability, but the individual species and their role in the ecosystem. In order to understand which species or species groups are the major players within marine ecosystems and how they relate to the functioning of the ecosystem, the understanding of biodiversity would have less emphasis on recording all the taxa, but rather on including the main species within the different functional or feeding groups. This implies a redundancy in the ecosystem, the so-called "rivet hypothesis" (Gray and Elliott, 2009). This also emphasizes the need for a functional view of biodiversity.

\section{Functional Ecosystem Biodiversity}

By interpreting biodiversity from an ecosystem (top-down) entry point, the focus shifts from structural to functional aspects. In order to construct a simple-to-use view, it is necessary to distinguish between the terms functions and processes (Figure 3; rectangular and rounded boxes, respectively) of which there are three main categories of ecosystem functions: (i) Primary production; (ii) Secondary production (spanning from the herbivorous primary consumers to the top predators), and (iii) Nutrient cycling. Each of these major functions are carried out through many inter-linked processes, such as photosynthesis, particle flux (sedimentation, mixing, and resuspension) and consumption/respiration. Export of energy from the marine system to humans and birds through selective biomass extraction also is considered a process as is the re-introduction of nutrients through effluents/run-off and guano.

Documenting the biodiversity status of these three major ecosystem functions/processes, through which they are carried out, requires measurable parameters and indicators (diamond-shaped boxes in Figure 3). Most of the indicators currently, or potentially, used in environmental assessment are regarded as surrogates (proxies) of the three main ecosystem functions (see Uusitalo et al., 2016), but the extent to which these reflect the processes is variable, and often just reflect structural elements of the ecosystem. Measuring the abundance and/or biomass of microalgae, the content or concentration of chlorophyll or various proxies such as fluorescence is commonly used to represent the amount of primary producers in the system (Steele, 1962), even if these indicators do not always directly measure photosynthesis. Similarly, for nutrient cycling, appropriate indicators may include the abundance or biomass of microbes or the conservative or otherwise behavior of the different nutrient forms, but this may not give sufficient knowledge of microbial activity (Caruso et al., $2015,2016)$. Secondary production, on the other hand, is more tangible, and there exist many indicators that are proxies for quantifying the distribution, population dynamics, abundance, and condition of the various categories of organisms, both in terms of functional traits and population and taxonomic composition (Diaz et al., 2004; Rice et al., 2012). Measuring the processes directly is somewhat more challenging because it often involves experimental approaches (for example respiration measurements), or long-term passive sampling (for example sediment traps) or repeated time-series of population dynamics, Allen-curves and biomass changes to allow production and productivity to be estimated (e.g., Crisp, 1984; Gray and Elliott, 2009), and these can be particularly time-consuming, expensive and not least of all, highly variable from daily, seasonal to annual scales (Bolam, 2014; Maire et al., 2015).

A unified approach to a biodiversity assessment with a functional ecosystem focus would therefore start by identifying indicators for the three main functions. Most assessment programmes will not include these functions, but their existence should at least be acknowledged. From there, the key processes and taxa within each of the major functions will be identified, first in general terms, and then in detail, specific to the assessment area in question. Furthermore, it is argued that there is an increasing emphasis in marine management, from the structural ecological approach in the EU Water Framework and Habitats Directives, to the more functional approach in the MSFD (Borja et al., 2010; Hering et al., 2010).

\section{Food-Web Biodiversity}

The food-web functional view (Figure 4) employs the three main ecosystem functions (primary production, secondary production and nutrient cycling) thus encompassing a range of processes (see Rombouts et al., 2013; Piroddi et al., 2015). The three ecosystem functions are carried out by various combinations of the structural components of biodiversity. Primary producers in the form of microorganisms, micro- and macroalgae as well as macrophytes (e.g., seagrasses), and including both photo- and chemosynthesis, exist in both the pelagic and benthic realms. Through the microbial loop and remineralization, microbes are responsible for the key function of nutrient cycling and make carbon available to the system (Azam et al., 1983; Fenchel, 2008). The primary herbivorous grazers such as copepods form the link between primary production and the rest of the food-web, although these also are transported out of the strictly marine 


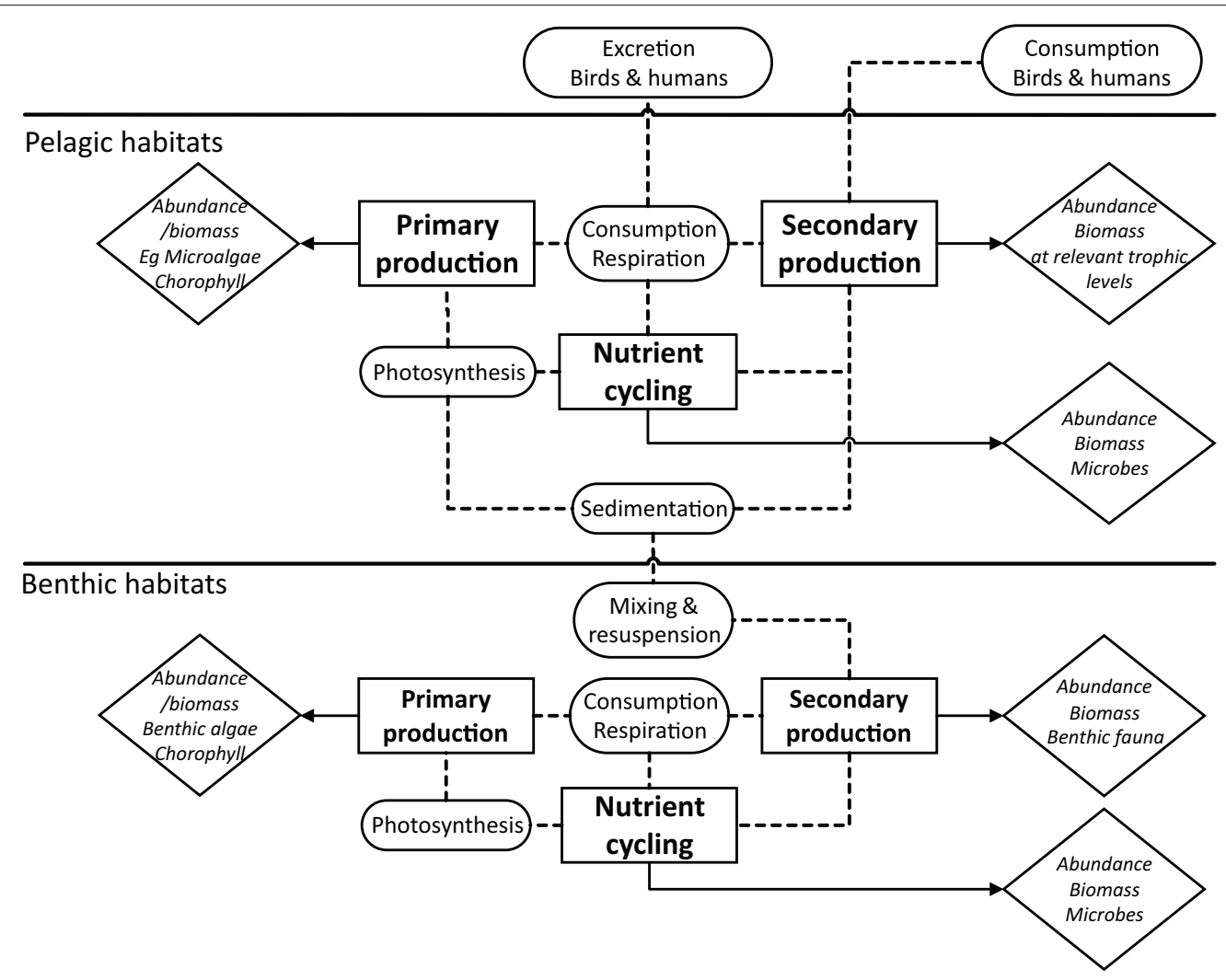

FIGURE 3 | Conceptual illustration of the major functions within marine ecosystems, as a basis for structuring ecosystem-orientated biodiversity assessments. Note that functions such as habitat provision, reproduction, etc., are implicit within the concept.

system through harvesting by seabirds and humans, as a source of omega-3 oil.

Thus, functional indicators of nutrient cycling can operate on microbes, primary production and secondary production to zooplankton, benthos and progressively higher-order predators. The processes typically are explored using more field-experimental, research-orientated indicators although the parameters or organisms to be measured within the three ecosystem functions depends on the biodiversity characteristics of the assessment area and the management questions being addressed.

In essence, a generalized food-web assessment requires indicators to cover all the major energy flow pathways throughout the system. Indicator selection would conceivably start at the producer level, such as abundance and biomass of phytoplankton and benthic algae, and also the basal zooplankton consumers. Indicators for motile components within the pelagic habitat would cover smaller components to top predators, assessed in categories appropriate to the survey area, but essentially covering, for example: (i) krill, gelatinous plankton, and juvenile fish, (ii) squid and small pelagic fish, (iii) large pelagic-feeding fish, reptiles, and mammals such as seals and finally (iv) large benthic feeding fish and mammals such as walrus and seals. The benthic secondary producing component can be seen in terms of functional groups, from herbivores (such as grazers), carnivores which actively seek prey and scavengers which consume both living and dead remains, to surface deposit feeders which consume material deposited from the planktonic realm, and filter-feeders that operate at the sediment-water interface, feeding on both settling particles as well as resuspended matter, the latter produced either through biological pumps or strong bottom currents.

\section{IMPLICATIONS FOR BIODIVERSITY ASSESSMENTS}

Different management questions require different starting-points for selection of measurement parameters and indicators for biodiversity assessments (Table 4).

\section{Structural Biodiversity Assessment}

The structural view on biodiversity is typically used when nature conservation is the primary focus in preserving all (or at least those designated as being important) biotic components of a given ecosystem together with its characteristic abiotic features. For example, the EC Habitats Directive requires assessing the biodiversity status, especially for the conservation features for which an area was designated, by using the appropriate taxonomic and habitat quality indicators. This either ignores the functional relationships within the ecosystem or makes the assumption that the structural elements are proxies for 


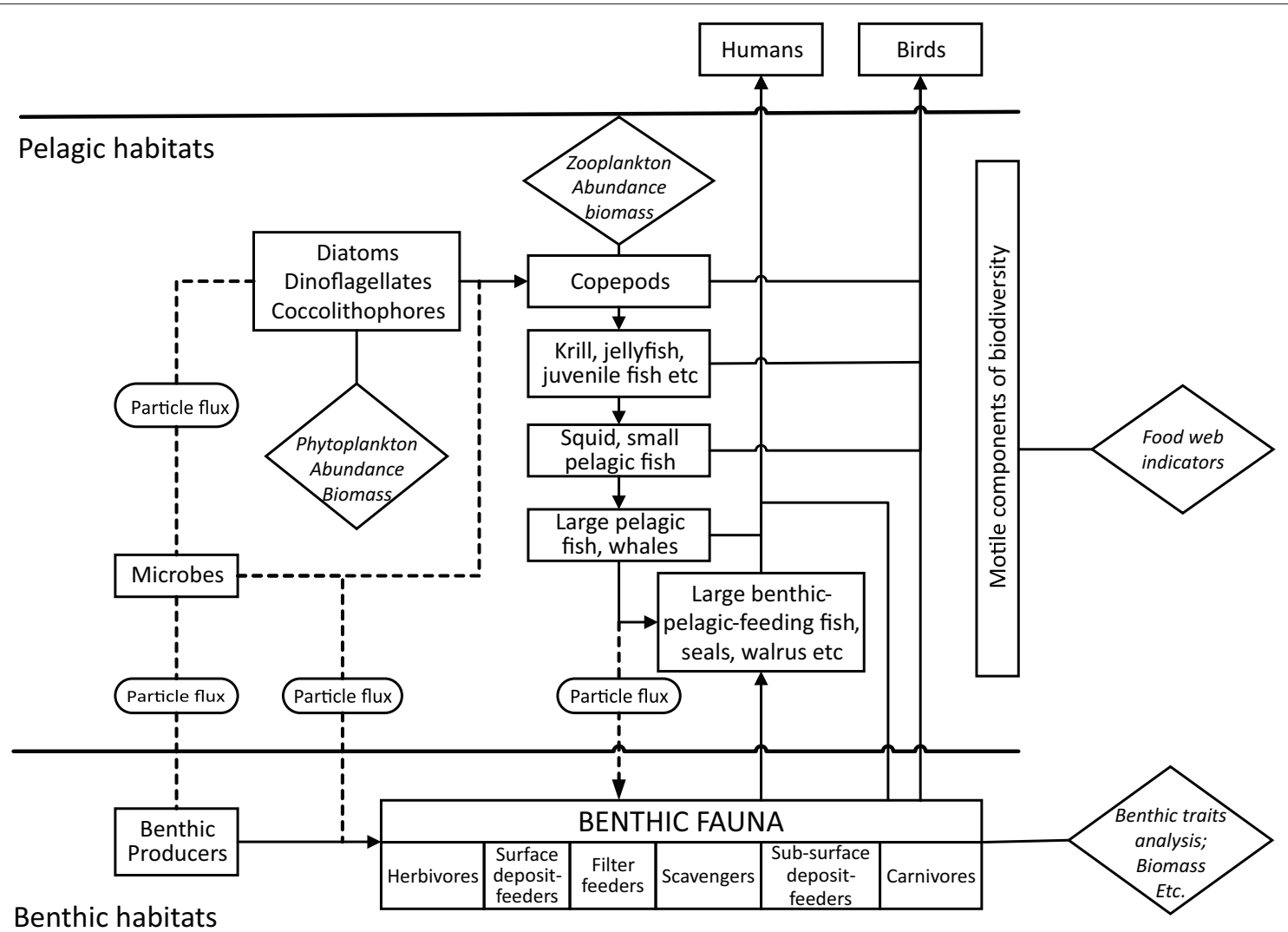

FIGURE 4 | Conceptual illustration of a generic marine food-web.

functioning. This can have implications for the management of such conservation areas since it may require manipulating the habitats and living conditions of certain species or communities when the assessment reveals a less favorable biodiversity status. In this case, ecoengineering may be required both to recreate and restore suitable eco-hydrological functioning (Type A ecoengineering) or to use the restocking or replanting to recreate populations (Type B ecoengineering) (Elliott et al., 2016). As an example, reef restoration is a measure to re-establish reef systems in places where these might have been damaged or lost. This requires the current habitat to be altered (e.g., from soft bottom to hard bottom) so it can support and promote the establishment of a new reef community. This structural change will be reflected in later biodiversity assessments and possibly document the increased biodiversity status. However, if the focus is on a structural view of biodiversity, it might not result in successful functioning and so this kind of biodiversity assessment will not be a holistic one. Hence, the context-driven approach maximizes taxonomical biodiversity but not necessarily ecosystem functioning. Although it can be assumed that biodiversity and ecosystem functioning relationships (BEF) will ensure that higher taxonomical biodiversity also produces higher ecosystem stability (in terms of resistance and resilience), there is insufficient evidence to support this assumption (Cardinale et al., 2012; Strong et al., 2015).

\section{Ecosystem Assessments}

Most management policies and assessments world-wide aim for some kind of ecosystem approach (Borja et al., 2008). The MSFD advocates an ecosystem-based approach, and many assessment and monitoring schemes exist aiming to integrate ecosystem functions and their values and services (see Atkins et al., 2011; Elliott, 2011, 2013, 2014; Laurila-Pant et al., 2015). However, as with the term biodiversity, the distinctions and uses of the terms Ecosystem Approach and Ecosystem-based management are far from consistent (see review in Borja et al., 2016). An Ecosystembased management strategy acknowledges the complexity of ecosystems and in particular: (i) the need to take into account both the structural aspects (e.g., life-forms present) and the interactions among organisms (especially inter-species relations) within ecological systems, (ii) the essence of connectivity between and within communities, ecosystems, habitats and biotopes, and (iii) that humans are a part of ecosystems thereby integrating human societies within biodiversity management (Elliott, 2011; Kelble et al., 2013; Long et al., 2015). This approach encompasses the structural and functional aspects of an ecosystem (its "emergent properties") as well as, at a smaller scale, the role of given subsystems or components from this ecosystem.

To that end, ecosystem assessments tend to employ at least two views on biodiversity: The structural taxonomic and the 
TABLE 4 | Examples of common managerial questions and the appropriate conceptual viewpoints, as starting-points for indicator selection for biodiversity assessments.

\begin{tabular}{|c|c|c|c|c|}
\hline Managerial questions & $\begin{array}{l}\text { Conceptual } \\
\text { viewpoints }\end{array}$ & Examples of indicators/methods & Informative value & Potential gaps \\
\hline $\begin{array}{l}\text { Conservation; } \\
\text { maximizing biodiversity }\end{array}$ & $\begin{array}{l}\text { Structural taxonomic } \\
\text { biodiversity }\end{array}$ & $\begin{array}{l}\text { Species abundance, richness, } \\
\text { diversity. Physical sampling and/or } \\
\text { visual methods. }\end{array}$ & $\begin{array}{l}\text { Informs of range of species present; } \\
\text { useful as reference conditions. }\end{array}$ & $\begin{array}{l}\text { Detailed observations made at } \\
\text { local scales may not always be } \\
\text { correctly upscaled to represent a } \\
\text { wider area. }\end{array}$ \\
\hline Eutrophication/Hypoxia & $\begin{array}{l}\text { Functional ecosystem } \\
\text { biodiversity, Structural } \\
\text { taxonomic biodiversity }\end{array}$ & $\begin{array}{l}\text { Productivity, harmful algal blooms, } \\
\text { seafloor species abundance, } \\
\text { richness, diversity, indicator taxa, } \\
\text { sediment profile analyses, physical } \\
\text { analyses of substrate }\left(\mathrm{O}_{2} \text { etc). }\right.\end{array}$ & $\begin{array}{l}\text { Informs of degradation status of } \\
\text { both the habitat and the faunal } \\
\text { communities. }\end{array}$ & $\begin{array}{l}\text { Assessments shall include } \\
\text { monitoring of water column quality, } \\
\text { i.e., nutrient levels and } \\
\text { phytoplankton. }\end{array}$ \\
\hline $\begin{array}{l}\text { Monitoring of seafloor } \\
\text { condition/ disturbance } \\
\text { (local scale) }\end{array}$ & $\begin{array}{l}\text { Structural taxonomic } \\
\text { biodiversity }\end{array}$ & $\begin{array}{l}\text { Species abundance, richness, } \\
\text { diversity, indicator taxa, substrate } \\
\text { condition, sediment profile } \\
\text { analyses. Physical sampling and/or } \\
\text { visual methods. }\end{array}$ & $\begin{array}{l}\text { Physical sampling gives rise to } \\
\text { quantitative indicators of seafloor } \\
\text { biodiversity and disturbance. Visual } \\
\text { methods give a broader overview of } \\
\text { conditions and visible disturbance } \\
\text { (e.g., smothering or abrasion). }\end{array}$ & $\begin{array}{l}\text { Visual and physical sampling can } \\
\text { cover only a relatively limited } \\
\text { spatial area (appropriate for } \\
\text { localized point-source } \\
\text { disturbance). Less informative for } \\
\text { more spatially extensive, but less } \\
\text { locally intensive disturbances. }\end{array}$ \\
\hline $\begin{array}{l}\text { Monitoring of water } \\
\text { column quality }\end{array}$ & $\begin{array}{l}\text { Functional ecosystem } \\
\text { biodiversity }\end{array}$ & $\begin{array}{l}\text { Abundance/ biomass e.g., of } \\
\text { microalgae, chlorophyll. Use of } \\
\text { physical sampling and/or remote or } \\
\text { in-situ sensors, biomarkers, areal or } \\
\text { satellite monitoring. }\end{array}$ & $\begin{array}{l}\text { Information on water quality } \\
\text { (parameters as relevant), early } \\
\text { warning system of change, } \\
\text { biological effects monitoring. }\end{array}$ & $\begin{array}{l}\text { Physical sampling or infrequent } \\
\text { remote measurements will not } \\
\text { capture short-term fluctuations, } \\
\text { but in-situ sensors will do so. } \\
\text { Organisms for bio-markers } \\
\text { integrate conditions over time. }\end{array}$ \\
\hline $\begin{array}{l}\text { Protection of coral } \\
\text { structures }\end{array}$ & $\begin{array}{l}\text { Structural taxonomic } \\
\text { biodiversity }\end{array}$ & $\begin{array}{l}\text { Species abundance, richness, } \\
\text { diversity. Reliance on visual and } \\
\text { acoustic methods; no physical } \\
\text { sampling. }\end{array}$ & $\begin{array}{l}\text { Acoustic methods can localize coral } \\
\text { structures over larger areas, and } \\
\text { visual methods used to verify } \\
\text { potential finds. }\end{array}$ & $\begin{array}{l}\text { Visual methods allow identification } \\
\text { of corals and larger epifauna (and } \\
\text { fish), but will underestimate } \\
\text { abundance and diversity of } \\
\text { burrowing or smaller organisms } \\
\text { utilizing the coral habitat. }\end{array}$ \\
\hline $\begin{array}{l}\text { Sustainable human } \\
\text { activities (broad-scale) }\end{array}$ & $\begin{array}{l}\text { Functional ecosystem } \\
\text { biodiversity, food-web } \\
\text { biodiversity }\end{array}$ & $\begin{array}{l}\text { Abundance and/or biomass of } \\
\text { primary producers (incl. microbes). } \\
\text { Productivity of key species or } \\
\text { trophic groups, proportion of } \\
\text { selected species at the top of } \\
\text { food-webs, abundance/distribution } \\
\text { of key trophic groups/species, } \\
\text { population dynamics modeling. }\end{array}$ & $\begin{array}{l}\text { Holistic assessment of biodiversity } \\
\text { at a broad, ecosystem scale. Useful } \\
\text { also for determining large-scale } \\
\text { impacts of local disturbances (e.g., } \\
\text { of seafloor). }\end{array}$ & $\begin{array}{l}\text { This topic is extensive so likely no } \\
\text { monitoring program will cover all of } \\
\text { these issues. A more detailed } \\
\text { question-driven selection of } \\
\text { indicators will be required. }\end{array}$ \\
\hline
\end{tabular}

functional ecosystem biodiversity. Both are used, or at least require to be used, in one single assessment, but require the need to keep overlaps minimal and to properly interpret the results when measures are to be taken on the basis of the assessment results. This, in turn, requires the need to interpret the resulting ecosystem status in both structural and functional ways so that managers can balance the different needs when planning management measures. As an example, Elliott (2011) proposed an ecosystem health assessment (or monitoring) programme consisting of four elements associated to the typical management cycle: (i) an analysis of main processes and structural characteristics of an ecosystem; (ii) an identification of known or potential stressors; (iii) the development of hypotheses about how those stressors may affect each part of the ecosystem, and (iv) the identification of measures of environmental quality and ecosystem health to test hypotheses. This encompasses and quantifies, from the socio-ecological system, the ecosystem services, and societal benefits approach (Atkins et al., 2011; Laurila-Pant et al., 2015). This approach has led to an extensive series of marine assessment systems which can include both the ecological health and societal well-being, for example the global Ocean Health Index (OHI) (Halpern et al., 2015; Borja et al., 2016).

In general, starting from the conceptual view of functional biodiversity, the clear distinction between ecosystem function and process (e.g., as proposed above) must be retained throughout the assessment and its interpretation when the terms are used to derive management actions from the indicators used to assess functions and processes. However, there is a notable lack of agreement throughout the literature regarding the terms "function" and "processes" when applied to ecosystems and their assessment; indeed the terms may be synonymous in that by definition a function is a rate process. In our functional ecosystem model, the three ecosystem functions (primary production, secondary production and nutrient cycling) together comprise holistic ecosystem functioning. These ecosystem functions are the sum of the physical, chemical and biological processes that transform and translocate energy and materials in ecosystems (Naeem, 1998; Paterson et al., 2012; Snelgrove et al., 2014; Borja et al., 2016). 
Functions, and thus inherently also the processes by which they are carried out, are central to the "ecosystem services" which the marine environment provides for its own sustainability and human benefits. As indicated above (and also see Turner and Schaafsma, 2015), successful structure and functioning of the physico-chemical and ecological systems can produce intermediate and final ecosystem services: (i) provisioning, (ii) regulating, (iii) supporting (or habitat), and (iv) culture and heritage (Jax, 2005; De Groot et al., 2010). Complementary human assets are then required to extract societal benefits from such services (Atkins et al., 2014). Strong et al. (2015) listed five categories of "ecosystem functions," which also refer to processes: (i) production of biomass, (ii) (non-living) organic matter transformation, (iii) ecosystem metabolism, (iv) nutrient cycling, and (v) physical environment modification, for which they analyzed biodiversity.

Thus, there are many ways to refer to the functions and processes occurring within marine ecosystems, and in turn the services and societal benefits which they provide. Focusing our conceptual understanding of biodiversity from a functional ecosystem viewpoint on three main functions, driven by a range of processes, gives clarity about the logical basis for both selection of assessment parameters and interpretation of results. We recognize that the functions themselves are assessed by measuring some proxy of the processes, such as various qualities and attributes of the organisms which carry out those processes. With this understanding, we can select the indicators which represent the sections of the system which best address the questions asked, and at the same time retain an awareness of the information gaps which require us to extrapolate information from other measurements and to make appropriate inferences for ecosystem-scale assessments.

\section{Food-Web Assessments}

The conceptual view outlined in Figure 4 provides the basis of a holistic food-web assessment. Typically, such assessments operate with a restricted set of parameters relating to predatorprey interactions, with a focus on abundance and population structure of commercially harvested species, and often also their main prey items. For example, the MSFD Descriptor 4 (trophic relations) adopted a pragmatic conceptual simplification in approach (Rogers et al., 2010; Rombouts et al., 2013). Two key attributes for food-webs were specified within the MSFD as: (i) energy flow in food-webs, i.e., from primary to secondary production, and (ii) structure of food-webs i.e., size and abundance of predators/prey (Rogers et al., 2010). Rombouts et al. (2013) argued that three main properties of foodwebs can be considered within the MSFD context: Structure, functioning and dynamics, with emphasis on the latter two and "the general principles that relate these three properties." The MSFD Descriptor 4 indicators for food-webs, such as the reproductive success of dominant piscivorous seabirds, are very much process-based and designed to capture responses to the multiple anthropogenic pressures that can affect food-webs, the main one being selective extraction of biomass (e.g., fishing).

The structuring influence of large predators on ecosystem stability, and the potential for human impacts thereon, can be illustrated, for example, by overfishing of the Atlantic cod, Gadus morhua which caused a notable increase in alpha and beta diversity of the remaining fish communities. These became more variable during periods where the cod no longer dominated the system (Ellingsen et al., 2015). This is an example of the difficulties a biodiversity concept will face when it becomes more complex. The overall assessment result will no longer be able to reflect both the structural and functional changes individually. The representability of an assessment of food-web status thus depends much on the indicators chosen and whether they are capable of capturing the "health" of the ecosystem, in terms of deviation from reference or target conditions (assuming these are in fact known and/or defined). Tett et al. (2013) emphasizes that the concept of ecosystem health is integral to management questions based on the overall assessment which thus encompasses an assessment of both biological diversity and the delivery of ecosystem services and societal benefits.

Where the aim of assessment is toward sustainable management, such as in the MSFD, or marine conservation, the selected food-web measurement parameters and indicators must focus on detecting the impacts of anthropogenic pressures (Coll et al., 2016). However, for a programme to understand the overall predator-prey structure in a system, all levels of interactions should be included into the underlying view on the biodiversity as the basis of the assessment. As with all aspects of biodiversity, changes in abiotic conditions such as climatic ones will also impact food-webs and create moving baselines against which changes in biodiversity are judged (Elliott et al., 2015). They are drivers for changes in species distributions, recruitment success and competition and so food-web indicators should operate at the species level (e.g., population indicators) but also at the ecosystem level when considering overall energy flow through the system.

The main practical challenge in finding fit-for-purpose foodweb indicators is the variability in pressure-impact relationships on their structure and functioning. An example on how to reach a more simplified generalization is the "fishing down the foodweb" rule (Pauly et al., 1998). It proposes that fishing a foodweb would first target larger and higher trophic level carnivorous fish and then progressively those at lower trophic levels, theoretically shortening food-webs. Thus, the mean trophic levels of consumers would be lower in an overfished food web, relative to an undisturbed one. An indicator reflecting the mean trophic level will adequately capture this aspect but other indicators will be needed when the aim of the assessment is not only to maintain sustainable fisheries, but also to preserve structural biodiversity. The corresponding conceptual view of biodiversity should be the basis of such preservation aims by including the relevant structural elements into the food-web but also assuming that such structural indicators are indeed proxies for successful functioning.

\section{CONCLUSIONS}

This review of the abstract concept of marine biodiversity is based on three conceptual views of the upper-level aspects 
of biodiversity (structural taxonomic, functional ecosystembased, and food-web biodiversity). They form the basis for constructing different biodiversity assessment types, depending on the context in which the assessment is used. The conceptual views serve as simplified common denominators from which can be developed a dialogue between both scientists and managers, balancing the needs for a sound scientific foundation and the pragmatic requirements for practical management of marine systems. The examples presented in this conceptual framework and the consequences for the assessment of biodiversity lead to three conclusions which improve the applicability and value of biodiversity status assessments and management.

Firstly, marine ecosystems are considered from different perspectives given the absence of a common and single understanding of what is marine biodiversity. The way in which we view this abstract biodiversity depends on various variables where this complexity can be simplified when focusing on the structural and functional elements of biodiversity that are important for the management question to be answered. This is best done using a carefully defined set of biodiversity elements to be assessed, knowing which elements to ignore and why and what consequences this has for the subsequent biodiversity assessment. This approach will allow for a context-driven assessment, where the meaning of the assessment result is pre-defined and derived from our applied understanding of biodiversity. The result does not need a special interpretation and is tied directly to the question we want to answer.

Secondly, we use the perspectives to construct a "management-friendly" assessment: A biodiversity status of "good" or "not good" needs a context for interpretation (see Mee et al., 2008). This context is given by the specific conceptual view. Together, this will provide information on what is the biodiversity status and how it can be improved by managing identified problems. Only an assessment that can explain the resulting biodiversity status and give insights into how the situation can be changed following management measures is useful for management. It is the conceptual view that leads to insights and measures to be applied by management thus emphasizing the need for knowledge on the biodiversity status and where and how it requires to be improved if it is considered to be degraded.

Thirdly, be aware of the limits and degree of quantification of the assessment: Since we know what has been omitted from our conceptual view, we also know what management cannot expect to achieve. Similarly, the success of management measures and their efficacy can only be determined by quantifying the conceptual approach. A primarily structural taxonomic view of biodiversity will not lead to an assessment that points to measures improving ecosystem functions. However, the conceptual view chosen allows us to determine the limits of our understanding of biodiversity and thus the possibilities of the management measures even before the assessment has been made. If the limits are clear and can be communicated, expectations are realistic whereas unrealistic expectations may arise from an incomplete conceptual approach or false assumptions of the links between structure and functioning.

A given conceptual view can always be expanded by including more elements and shifting the focus closer to the question asked. As one example, we can include activities which create the major pathways of human pressures, the state changes they involve in the marine system and the impacts this has on society, its welfare and well-being (Scharin et al., 2016; Smith et al., 2016). Such modifications will expand our understanding of biodiversity using the influential parameters relevant for the specific purpose of the individual biodiversity assessment.

\section{AUTHOR CONTRIBUTIONS}

The basis for this manuscript was conceived during a pivotal discussion between SC, JA, TB, and P. Herman, Bilbao, November 2013, the first three of which produced the initial draft of the manuscript. The remaining authors each have contributed within various areas of expertise: $\mathrm{HB}, \mathrm{AB}, \mathrm{JC}$, and $\mathrm{HH}$ (indicators and environmental assessments), ME (general concepts and management), NN (food webs) and PR (ecosystem functions and processes).

\section{ACKNOWLEDGMENTS}

This manuscript is a result of DEVOTES (DEVelopment Of innovative Tools for understanding marine biodiversity and assessing good Environmental Status) project, funded by the European Union under the 7th Framework Programme, "The Ocean of Tomorrow" Theme (grant agreement no. 308392), www.devotes-project.eu. We acknowledge the life's work of the late Prof. Carlo Heip, for leading initiatives such as BIOMARE and the MarBEF network, which have sown the seeds for this present work. Further, we thank Peter Hermann, Anne Chenuil, and Chris Lynam. We also acknowledge the other members of the MSFD TG1 group, particularly David Connor and Per Nilsson, for together developing the criteria and indicators for biodiversity, adopted by the MSFD. The lead author sincerely thanks colleagues, collaborators and clients for all the countless discussions, understandings and misunderstandings, which have given rise to this manuscript, as well as Tom Pearson for past mentoring in benthic indicators and functional traits. Finally, thanks to two reviewers, particularly Christos Arvanitides, whose constructive criticism much improved this manuscript.

\section{REFERENCES}

Atkins, J. P., Burdon, D., Elliott, M., and Gregory, A. J. (2011). Management of the marine environment: integrating ecosystem services and societal benefits with the DPSIR framework in a systems approach. Mar. Pollut. Bull. 62, 215-226. doi: 10.1016/j.marpolbul.2010.12.012

Atkins, J. P., Burdon, D., Elliott, M., Schaafsma, M., and Turner, R. K. (2014). Coastal and marine ecosystem services. Environ. Sci. 23, 26-30.

Azam, F., Fenchel, T., Field, J. G., Gray, J. S., Meyerreil, L. A., and Thingstad, F. (1983). The ecological role of water-column microbes in the sea. Mar. Ecol. Prog. Ser. 10, 257-263. doi: 10.3354/meps 010257 
Bartkowski, B., Lienhoop, N., and Hansjuergens, B. (2015). Capturing the complexity of biodiversity: a critical review of economic valuation studies of biological diversity. Ecol. Econ. 113, 1-14. doi: 10.1016/j.ecolecon.2015. 02.023

Bengtsson, J. (1998). Which species? What kind of diversity? Which ecosystem function? Some problems in studies of relations between biodiversity and ecosystem function. Appl. Soil Ecol. 10, 191-199. doi: 10.1016/S0929-1393(98)00120-6

Berg, T., Fürhaupter, K., Teixeira, H., Uusitalo, L., and Zampoukas, N. (2015). The marine strategy framework directive and the ecosystembased approach - pitfalls and solutions. Mar. Pollut. Bull. 96, 18-28. doi: 10.1016/j.marpolbul.2015.04.050

Boero, F. (2010). The study of species in the era of biodiversity: a tale of stupidity. Diversity 2:115. doi: 10.3390/d2010115

Bolam, S. G. (2014). Macrofaunal recovery following the intertidal recharge of dredged material: a comparison of structural and functional approaches. Mar. Environ. Res. 97, 15-29. doi: 10.1016/j.marenvres.2014.01.008

Borja, A., Bricker, S. B., Dauer, D. M., Demetriades, N. T., Ferreira, J. G., Forbes, A. T., et al. (2008). Overview of integrative tools and methods in assessing ecological integrity in estuarine and coastal systems worldwide. Mar. Pollut. Bull. 56, 1519-1537. doi: 10.1016/j.marpolbul.2008.07.005

Borja, A., Elliott, M., Andersen, J. H., Berg, T., Carstensen, J., Halpern, B. S., et al. (2016). Overview of integrative assessment of marine systems: the ecosystem approach in practice. Front. Mar. Sci. 3:20. doi: 10.3389/fmars.2016. 00020

Borja, A., Elliott, M., Andersen, J. H., Cardoso, A. C., Carstensen, J., Ferreira, J. G., et al. (2013). Good Environmental Status of marine ecosystems: what is it and how do we know when we have attained it? Mar. Pollut. Bull. 76, 16-27. doi: 10.1016/j.marpolbul.2013.08.042

Borja, A., Elliott, M., Carstensen, J., Heiskanen, A.-S., and van de Bund, W. (2010). Marine management - towards an integrated implementation of the european marine strategy framework and the water framework directives. Mar. Pollut. Bull. 60, 2175-2186. doi: 10.1016/j.marpolbul.2010.09.026

Borja, A., Muxika, I., and Franco, J. (2003). The application of a Marine Biotic Index to different impact sources affecting soft-bottom benthic communities along European coasts. Mar. Pollut. Bull. 46, 835-845. doi: $10.1016 /$ S0025-326X(03)00090-0

Boyes, S. J., Elliott, M., (2014). Marine legislation - The ultimate 'horrendogram': international law, European directives \& national implementation. Mar. Poll. Bull. 86, 39-47. doi: 10.1016/j.marpolbul.2014.06.055

Bremner, J., Rogers, S. I., and Frid, C. L. J. (2006a). Matching biological traits to environmental conditions in marine benthic ecosystems. J. Mar. Sys. 60, 302-316. doi: 10.1016/j.jmarsys.2006.02.004

Bremner, J., Rogers, S. I., and Frid, C. L. J. (2006b). Methods for describing ecological functioning of marine benthic assemblages using biological traits analysis (BTA). Ecol. Indic. 6, 609-622. doi: 10.1016/j.ecolind.2005.08.026

Brooks, T. M., Akçakaya, H. R., Burgess, N. D., Butchart, S. H. M., HiltonTaylor, C., Hoffmann, M., et al. (2016). Analysing biodiversity and conservation knowledge products to support regional environmental assessments. Sci. Data 3:160007. doi: $10.1038 /$ sdata.2016.7

Cardinale, B. J., Duffy, J. E., Gonzalez, A., Hooper, D. U., Perrings, C., Venail, P., et al. (2012). Biodiversity loss and its impact on humanity. Nature 486, 59-67. doi: 10.1038/nature11148

Caruso, G., La Ferla, R., Azzaro, M., Zoppini, A., Marino, G., Petochi, T., et al. (2015). Microbial assemblages for environmental quality assessment: knowledge, gaps and usefulness in the European Marine Strategy Framework Directive. Crit. Rev. Microbiol. 42, 883-904. doi: 10.3109/1040841X.2015.1087380

Caruso, G., M., Azzaro, C., Caroppo, F., Decembrini, L. S., Monticelli, M., Leonardi, G., et al. (2016). Microbial community and its potential as descriptor of environmental status. ICES J. Mar. Sci. 73, 2174-2177. doi: 10.1093/icesjms/fsw101

CBD (1992). Convention on Biological Diversity. Rio Earth Summit, 5 June 1992. Convention on Biological Diversity.

Cochrane, S. K. J., Connor, D. W., Nilsson, P., Mitchell, I., Reker, J., Franco, J., et al. (2010). Marine Strategy Framework Directive Task Group 1 Report: Biological Diversity. EUR 24337 EN - Joint Research Centre, Luxembourg, Office for Official Publications of the European Communities, 110.
Cochrane, S. K. J., Pearson, T. H., Greenacre, M., Costelloe, J., Ellingsen, I. H., Dahle, S., et al. (2012). Benthic fauna and functional traits along a Polar Front transect in the Barents Sea - Advancing tools for ecosystem-scale assessments. J. Mar. Sys. 94, 204-217. doi: 10.1016/j.jmarsys.2011.12.001

Coll, M., Shannon, L. J., Kleisner, K. M., Juan-Jordá, M. J., Bundy, A., Akoglu, A. G., et al. (2016). Ecological indicators to capture the effects of fishing on biodiversity and conservation status of marine ecosystems. Ecol. Indic. 60, 947-962. doi: 10.1016/j.ecolind.2015.08.048

Costanza, R., D’arge, R., De Groot, R., Farber, S., Grasso, M., Hannon, B., et al. (1997). The value of the world's ecosystem services and natural capital. Nature 387, 235-260. doi: 10.1038/387253a0

Costanza, R., De Groot, R., Sutton, P., Van Der Ploeg, S., Anderson, S. J., Kubiszewski, I., et al. (2014). Changes in the global value of ecosystem services. Global Environ. Change 26, 152-158. doi: 10.1016/j.gloenvcha.2014.04.002

Crisp, D. J. (1984). "Energy flow measurements," in Methods for the Study of Marine Benthos, eds N. A. Holme and N. A. McIntyre (Oxford: Blackwell), 284-372.

De Groot, R. S., Alkemade, R., Braat, L., Hein, L., and Willemen, L. (2010). Challenges in integrating the concept of ecosystem services and values in landscape planning, management and decision making. Ecol. Complex 7, 260-272. doi: 10.1016/j.ecocom.2009.10.006

De Groot, R. S., Wilson, M. A., and Boumans, R. M. J. (2002). A typology for the classification, description and valuation of ecosystem functions, goods and services. Ecol. Econ. 41, 393-408. doi: 10.1016/S0921-8009(02)00089-7

deyoung, B., Barange, M., Beaugrand, G., Harris, R., Perry, R. I., Scheffer, M., et al. (2008). Regime shifts in marine ecosystems: detection, prediction and management. Trends Ecol. Evol. 23, 402-409. doi: 10.1016/j.tree.2008.03.008

Diaz, R. J., Solan, M., and Valente, R. M. (2004). A review of approaches for classifying benthic habitats and evaluating habitat quality. J. Environ. Manag. 73, 165-181. doi: 10.1016/j.jenvman.2004.06.004

Duarte, C. M., and Cebrian, J. (1996). The fate of marine autotrophic production. Limnol. Oceanogr. 41, 1758-1766. doi: 10.4319/lo.1996.41.8.1758

Ellingsen, K. E., Anderson, M. J., Shackell, N. L., Tveraa, T., Yoccoz, N. G., and Frank, K. T. (2015). The role of a dominant predator in shaping biodiversity over space and time in a marine ecosystem. J. Anim. Ecol. 84, 1242-1252. doi: $10.1111 / 1365-2656.12396$

Elliott, M. (2011). Marine science and management means tackling exogenic unmanaged pressures and endogenic managed pressures - A numbered guide. Mar. Pollut. Bull. 62, 651-655. doi: 10.1016/j.marpolbul.2010.11.033

Elliott, M. (2013). The 10-tenets for integrated, successful and sustainable marine management. Mar. Pollut. Bull. 74, 1-5. doi: 10.1016/j.marpolbul.2013.08.001

Elliott, M. (2014). Integrated marine science and management: wading through the morass. Mar. Pollut. Bull. 86, 1-4. doi: 10.1016/j.marpolbul.2014.07.026

Elliott, M., Borja, A., Mcquatters-Gollop, A., Mazik, K., Birchenough, S., Andersen, J. H., et al. (2015). Force majeure: will climate change affect our ability to attain Good Environmental Status for marine biodiversity? Viewpoint. Mar. Pollut. Bull. 95, 7-27. doi: 10.1016/j.marpolbul.2015.03.015

Elliott, M., Mander, L., Mazik, K., Simenstad, C., Valesini, F., Whitfield, A., et al. (2016). Ecoengineering with Ecohydrology: successes and failures in estuarine restoration. Estuar. Coast. Shelf Sci. 176, 12-35. doi: 10.1016/j.ecss.2016.04.003

Elliott, M., and Quintino, V. (2007). The estuarine quality paradox, environmental homeostasis and the difficulty of detecting anthropogenic stress in naturally stressed areas. Mar. Pollut. Bull. 54, 640-645. doi: 10.1016/j.marpolbul.2007.02.003

European Commission (2008). Directive 2008/56/EC of the European Parliament and of the Council of 17 June 2008 Establishing a Framework for Community Action in the Field of Marine Environmental Policy (Marine Strategy Framework Directive). Official Journal of the European Union L 164/19.

European Commission (2010). Commission Decision of 1 September 2010 on Criteria and Methodological Standards on Good Environmental Status of Marine Waters (Notified Under Document C(201, 0) 5956). Official Journal of the European Union L 232/14.

Farnsworth, K. D., Adenuga, A. H., and De Groot, R. S. (2015). The complexity of biodiversity: a biological perspective on economic valuation. Ecol. Econ. 120, 350-354. doi: 10.1016/j.ecolecon.2015.10.003

Fenchel, T. (2008). The microbial loop-25 years later. J. Exp. Mar. Biol. Ecol. 366, 99-103. doi: 10.1016/j.jembe.2008.07.013

Galparsoro, I., Connor, D. W., Borja, A., Aish, A., Amorim, P., Bajjouk, T., et al. (2012). Using EUNIS habitat classification for benthic mapping in European 
seas: present concerns and future needs. Mar. Pollut. Bull. 64, 2630-2638. doi: 10.1016/j.marpolbul.2012.10.010

Galparsoro, I., German Rodriguez, J., Menchaca, I., Quincoces, I., Mikel Garmendia, J., and Borja, A. (2015). Benthic habitat mapping on the Basque continental shelf (SE Bay of Biscay) and its application to the European Marine Strategy Framework Directive. J. Sea Res. 100, 70-76. doi: 10.1016/j.seares.2014.09.013

Gamfeldt, L., Lefcheck, J. S., Byrnes, J. E. K., Cardinale, B. J., Duffy, J. E., and Griffin, J. N. (2015). Marine biodiversity and ecosystem functioning: what's known and what's next? Oikos 124, 252-265. doi: 10.1111/oik.01549

Gray, J. S., and Elliott, M. (2009). Ecology of Marine Sediments: from Science to Management. Oxford: Oxford University Press.

Halpern, B. S., Longo, C., Lowndes, J. S., Best, B. D., Frazier, M., Katona, S. K., et al. (2015). Patterns and emerging trends in global ocean health. PLoS ONE 10:e0117863. doi: 10.1371/journal.pone.0117863

Heip, C. (1998). Marine biodiversity. Biofutur 179, 12-17. doi: 10.1016/S0294-3506(98)80005-7

Heip, C. (2003). "What structures Marine biodiversity and why does it vary?," in Marine Science Frontiers for Europe, eds G. Wefer, F. Lamy, and F. Mantoura (Berlin; Heidelberg: Springer), 251-264.

Hemminga, M. A., and Duarte, C. M. (2000). Seagrass Ecology. Cambridge: Cambridge University Press.

Hering, D., Borja, A., Carstensen, J., Carvalho, L., Elliott, M., Feld, C. K., et al. (2010). The European Water Framework Directive at the age of 10: a critical review of the achievements with recommendations for the future. Sci. Tot. Environ. 408, 4007-4019. doi: 10.1016/j.scitotenv.2010.05.031

Hooper, D. U., Chapin, F. S., Ewel, J. J., Hector, A., Inchausti, P., Lavorel, S., et al. (2005). Effects of biodiversity on ecosystem functioning: a consensus of current knowledge. Ecol. Monogr. 75, 3-35. doi: 10.1890/04-0922

Hummel, H., Frost, M., Juanes, J. A., Kochmann, J., Bolde, C. F. C. P., Aneiros, F., et al. (2015). A comparison of the degree of implementation of marine biodiversity indicators by European countries in relation to the Marine Strategy Framework Directive (MSFD). J. Mar. Biol. Assoc. UK. 95, 1519-1531. doi: $10.1017 /$ S0025315415000235

ICES (2009). Report of the Working Group on Seabird Ecology (WGSE). International Council for the Exploration of the Sea. ICES CM 2009/LRC:05.

Isbell, F., Craven, D., Connolly, J., Loreau, M., Schmid, B., Beierkuhnlein, C., et al. (2015a). Biodiversity increases the resistance of ecosystem productivity to climate extremes. Nature 526, 574-577. doi: 10.1038/nature 15374

Isbell, F., Tilman, D., Polasky, S., and Loreau, M. (2015b). The biodiversity-dependent ecosystem service debt. Ecol. Lett. 18, 119-134. doi: $10.1111 /$ ele. 12393

Jax, K. (2005). Function and "functioning" in ecology: what does it mean? Oikos 111, 641-648. doi: 10.1111/j.1600-0706.2005.13851.x

Kelble, C. R., Loomis, D. K., Lovelace, S., Nuttle, W. K., Ortner, P. B., Fletcher, P., et al. (2013). The EBM-DPSER conceptual model: integrating ecosystem services into the DPSIR Framework. PLoS ONE 8:e70766. doi: 10.1371/journal.pone.0070766

Kenchington, E. L. (2003). Responsible Fisheries in the Marine Ecosystem. Wallingford: CBAI Publishing.

Klein, C. J., Brown, C. J., Halpern, B. S., Segan, D. B., McGowan, J., Beger, M., et al. (2015). Shortfalls in the global protected area network at representing marine biodiversity. Sci. Rep. 5:17539. doi: 10.1038/srep17539

Laurila-Pant, M., Lehikoinen, A., Uusitalo, L., and Venesjärvi, R. (2015). How to value biodiversity in environmental management? Ecol. Indic. 55, 1-11. doi: 10.1016/j.ecolind.2015.02.034

Linné, C. (1735). Systema Naturae Per Regna Tria Naturae, Secundum Classes, Ordines, Genera, Species, Cum Characteribus, Differentiis, Synonymis, Locis. Leiden: Ex typographia Johannis Wilhelmi de Groot.

Long, R. D., Charles, A., and Stephenson, R. L. (2015). Key principles of marine ecosystem-based management. Mar. Policy 57, 53-60. doi: 10.1016/j.marpol.2015.01.013

Loreau, M. (2000). Biodiversity and ecosystem functioning: recent theoretical advances. Oikos 91, 3-17. doi: 10.1034/j.1600-0706.2000.910101.x

Loreau, M., and Hector, A. (2001). Partitioning selection and complimentarity in biodiversity experiments. Nature 412, 72-76. doi: 10.1038/35083573

Maire, E., Grenouillet, G., Brosse, S., and Villeger, S. (2015). How many dimensions are needed to accurately assess functional diversity? A pragmatic approach for assessing the quality of functional spaces. Global Ecol. Biogeogr. 24, 728-740. doi: 10.1111/geb.12299

McCann, K. S. (2000). The diversity-stability debate. Nature 405, 228-233. doi: $10.1038 / 35012234$

Mee, L. D., Jefferson, R. L., Laffoley, D. d., and Elliott, M. (2008). How good is good? human values and Europe's proposed Marine Strategy Directive. Mar. Pollut. Bull. 56, 187-204. doi: 10.1016/j.marpolbul.2007.09.038

Naeem, S. (1998). Species redundancy and ecosystem reliability. Conserv. Biol. 12, 39-45. doi: 10.1046/j.1523-1739.1998.96379.x

Olenin, S., and Ducrotoy, J. P. (2006). The concept of biotope in marine ecology and coastal management. Mar. Pollut. Bull. 53, 20-29. doi: 10.1016/j.marpolbul.2006.01.003

Olsgard, F., and Gray, J. S. (1995). A comprehensive analysis of the effects of offshore oil and gas exploration and production on the benthic communities of the Norwegian continental shelf. Mar. Ecol. Prog. Ser. 122, 277-306. doi: $10.3354 /$ meps 122277

Orth, R. J., Carruthers, T. J. B., Dennison, W. C., Duarte, C. M., Fourqurean, J. W., Heck, K. L. Jr., et al. (2006). A global crisis for seagrass ecosystems. Bioscience 56, 987-996. doi: 10.1641/0006-3568(2006)56[987:AGCFSE]2.0.CO;2

Palumbi, S. R. (2003). Population genetics, demographic connectivity, and the design of marine reserves. Ecol. Appl. 13, 146-158. doi: 10.1890/1051-0761(2003)013[0146:PGDCAT]2.0.CO;2

Paterson, D. M., Defew, E. C., and Jabour, J. (2012). "Ecosystem function and co-evolution of terminology in marine science and management," in Marine Biodiversity and Ecosystem Functioning: Frameworks, methodologies, and integration, eds M. Solan, R. J. Aspden and D. M. Paterson (Oxford: Oxford University Press), 1-240.

Pauly, D., Christensen, V. V., Dalsgaard, J., Froese, R., and Torres, F. Jr. (1998). Fishing down marine food webs. Science 279, 860-863. doi: $10.1126 /$ science. 279.5352 .860

Pearson, T. H., and Rosenberg, R. (1978). Macrobenthic succession in relation to organic enrichment and pollution of the marine environment. Oceanogr. Mar. Biol. Ann. Rev. 16, 229-331.

Pimm, S. L., Jenkins, C. N., Abell, R., Brooks, T. M., Gittleman, J. L., Joppa, L. N., et al. (2014). The biodiversity of species and their rates of extinction, distribution, and protection. Science 344, 6187. doi: 10.1126/science.12 46752

Piroddi, C., Teixeira, H., Lynam, C. P., Smith, C., Alvarez, M. C., Mazik, K., et al. (2015). Using ecological models to assess ecosystem status in support of the european marine strategy framework directive. Ecol. Indic. 58, 175-191. doi: 10.1016/j.ecolind.2015.05.037

Queiros, A. M., J. A., Strong, K., Mazik, J., Carstensen, J., Bruun, P. J., et al. (2016). An objective framework to test the quality of candidate indicators of good environmental status. Front. Mar. Sci. 3:73. doi: 10.3389/fmars.2016.00073

Reiss, H., Birchenough, S., Borja, A., Buhl-Mortensen, L., Craeymeersch, J., Dannheim, J., et al. (2015). Benthos distribution modelling and its relevance for marine ecosystem management. ICES J. Mar. Sci. 72, 297-315. doi: 10.1093/icesjms/fsu107

Rice, J., Arvanitidis, C., Borja, A., Frid, C., Hiddink, J. G., Krause, J., et al. (2012). Indicators for Sea-floor integrity under the european marine strategy framework directive. Ecol. Indic. 12, 174-184. doi: 10.1016/j.ecolind.2011.03.021

Rogers, S. I., Casini, M., Cury, P., Heath, M., Irigoien, I., Kuosa, H., et al. (2010). Marine Strategy Framework Directive Task Group 5 Report: Food Webs. EUR 24343 EN - Joint Research Centre, Luxembourg: Office for Official Publications of the European Communities, 55.

Rombouts, I., Beaugrand, G., Fizzala, X., Gaill, F., Greenstreet, S. P. R., Lamare, S., et al. (2013). Food web indicators under the marine strategy framework directive: from complexity to simplicity? Ecol. Indic. 29, 246-254. doi: 10.1016/j.ecolind.2012.12.021

Rosenberg, R., Nilsson, H. C., and Diaz, R. J. (2001). Response of benthic fauna and changing sediment redox profiles over a hypoxic gradient. Estuar. Coast. Shelf Sci. 53, 343-350. doi: 10.1006/ecss.2001.0810

Sarkar, S., and Margules, C. (2002). Operationalizing biodiversity for conservation planning. J. Biosci. 27, 299-308. doi: 10.1007/BF02704961

Scharin, H., Ericsdotter, S., Elliott, M., Turner, R. K., Niiranen, S., Blenckner, T., et al. (2016). Processes for the sustainable stewardship of marine environments. Ecol. Econ. 128, 55-67. doi: 10.1016/j.ecolecon.2016.04.010 
Selig, E. R., Longo, C., Halpern, B. S., Best, B. D., Hardy, D., Elfes, C. T., et al. (2013). Assessing global marine biodiversity status within a coupled socio-ecological perspective. PLoS ONE 8:e60284. doi: 10.1371/journal.pone.0060284

Smith, C. J., Papadopoulou, K.-N., Barnard, S., Mazik, K., Elliott, M., Patrício, J., et al. (2016). Managing the marine environment, conceptual models and assessment: considerations for the european marine strategy framework directive. Front. Mar. Sci. 3:144. doi: 10.3389/fmars.2016.00144

Snelgrove, P. V., Thrush, S. F., Wall, D. H., and Norkko, A. (2014). Real world biodiversity-ecosystem functioning: a seafloor perspective. Trends Ecol. Evol. 29, 398-405. doi: 10.1016/j.tree.2014.05.002

Solan, M., Raffaelli, D. G., Paterson, D. M., White, P. C. L., and Pierce, G. J. (2006). Marine biodiversity and ecosystem function: empirical approaches and future research needs - Introduction. Mar. Ecol. Prog. Ser. 311, 175-178. doi: $10.3354 /$ meps311175

Steele, J. H. (1962). Environmental control of photosynthesis in the sea. Limnol. Oceanogr. 7, 137-150. doi: 10.4319/lo.1962.7.2.0137

Strong, J. A., Andonegi, E., Bizsel, K. C., Danovaro, R., Elliott, M., Franco, A., et al. (2015). Marine biodiversity and ecosystem function relationships: the potential for practical monitoring applications. Estuar. Coast. Shelf Sci. 161, 46-64. doi: 10.1016/j.ecss.2015.04.008

Teixeira, H., T., Berg, L., Uusitalo, K., Fürhaupter, A.-S., Heiskanen, K., et al. (2016). A catalogue of marine biodiversity indicators. Front. Mar. Sci. 3:207. doi: 10.3389/fmars.2016.00207

Tett, P., Gowen, R. J., Painting, S. J., Elliott, M., Forster, R., Mills, D. K., et al. (2013). Framework for understanding marine ecosystem health. Mar. Ecol. Prog. Ser. 494, 1-27. doi: 10.3354/meps10539

Turner, R. K., and Schaafsma, M. (2015). Coastal Zones Ecosystem Services: From Science to Values and Decision Making. Cham: Springer International Publication.

Uusitalo, L. H., Blanchet, J., Andersen, O., Beauchard, T., Berg, S., Bianchelli, A., et al. (2016). Indicator-based assessment of marine biological diversity lessons from 10 case studies across the European Seas. Front. Mar. Sci. 3:159. doi: 10.3389/fmars.2016.00159 van den Belt, M., and Costanza, R. (2012). "Ecological economics of estuaries and coasts," in Treatise on Estuarine and Coastal Science, eds E. Wolanski, D. McLusky, M. van den belt, and R. Costanza (Waltham, MA: Academic Press), 525.

Wang, S., and Loreau, M. (2016). Biodiversity and ecosystem stability across scales in metacommunities. Ecol. Lett. 19, 510-518. doi: 10.1111/ele. 12582

Wilson, E. O. (1988). “The Current State of Biodiversity," in Biodiversity, eds E. O. Wilson and F. M. Peter. (Washington, DC: National Academy Press), 3-20.

Wilson, E. O. (1985). The biological diversity crisis. BioScience 35, 700-706. doi: $10.2307 / 1310051$

Yachi, S., and Loreau, M. (1999). Biodiversity and ecosystem productivity in a fluctuating environment: the insurance hypothesis. Proc. Nat. Acad. Sci. U.S.A. 96, 1463-1468. doi: 10.1073/pnas.96.4.1463

Zacharius, M. A., and Roff, J. C. (2000). Hierarchical ecological approach to conserving Marine biodiversity. Conserv. Biol. 15, 1327-1334. doi: 10.1046/j.1523-1739.2000.99191.x

Conflict of Interest Statement: The authors declare that the research was conducted in the absence of any commercial or financial relationships that could be construed as a potential conflict of interest.

The handling Editor MM declared a collaboration with the authors and states that the process nevertheless met the standards of a fair and objective review.

Copyright (c) 2016 Cochrane, Andersen, Berg, Blanchet, Borja, Carstensen, Elliott, Hummel, Niquil and Renaud. This is an open-access article distributed under the terms of the Creative Commons Attribution License (CC BY). The use, distribution or reproduction in other forums is permitted, provided the original author(s) or licensor are credited and that the original publication in this journal is cited, in accordance with accepted academic practice. No use, distribution or reproduction is permitted which does not comply with these terms. 